\title{
Virtuous Physician: Indonesian Perspective
}

\section{Kusmaryanto CB* \\ Graduate School, Sanata Dharma University, Indonesia}

*Corresponding author: Carolus Boromeus Kusmaryant, Graduate School, Sanata Dharma University, Jln. Kaliurang Km. 7, Yogyakarta, 55281, Indonesia, Tel: +6281328888911, Email: kusmaryanto@gmail.com

\section{Review Article}

Volume 4 Issue 1

Received Date: January 30, 2021

Published Date: February 15, 2021

DOI: $10.23880 / a b c a-16000159$

\section{Abstract}

Physicians are virtuous profession because they deal with life and death and especially with vulnerable persons. It is a humanity profession. To be good physicians need to have high standard of compassion and care (virtue). Medical virtues have to be taught in the faculty of medicine so that the alumni have virtuous character. In their lives as physician, there are many regulations to maintain the application of virtue in their services. Unfortunately, now the erosion of virtues becomes more apparent. Some physicians are more profit-oriented rather than humanity-oriented.

Keywords: Virtuous Physician; Virtue Ethics; Vulnerable Persons; Medical Code of Conduct; Hippocrates Oath; Minus Malum; Maximum Bonum; Indonesia

\section{Introduction}

Etymologically the word Virtue came from Latin words 'virtus' signifies manliness or courage. Virtue in its widest sense means the excellence of perfection of a thing. While in its strictest perspective signifies a habit superadded to a faculty of the soul and its readiness to act conformable to our rational nature which often used by moral philosopher.

The word 'patient' came from Latin word patǐens patientis, which means to 'suffer' and also 'powerless'. So patient literally means those who suffer and powerless. Patients suffer because of their illness which affects all of their existence that forbid them to live as usual. Furthermore, they are powerless because they don't know how to overcome their problem.

For healthcare workers, virtue is very important because they deal with life and death and especially with vulnerable persons. A patient is a vulnerable person who needs special attention from the medical doctors. In dealing with those kinds of people, certainly physicians need to have high standard of compassion and care as an important part of their daily lives. We need virtuous physicians so that patients are treated well. It is not enough to act as if they dealt with healthy people. That is why, for centuries virtue ethics become the conceptual foundation for medical ethics since virtues are essential elements to be a good person and living a good life.

\section{Virtues}

The long history of virtue ethics has dated back to the ancient Greek philosophers, especially Aristotle (385-322 BC) on his books Nicomachean Ethics, Magna Moralia, and Eudemian Ethics. For Aristotle, the aims of ethics are to act well and to be a good person (Nicomachean Ethics no $1102 \mathrm{~b}$ 26 and $1144 \mathrm{~b} 18$ ). The good has been aptly described as that at which everything aims (Nicomachean Ethics No. 1099 a) [1]. So in pursuit of individual good, virtues are indispensable way to walk on since the virtue of a human being will be the state that makes a human being good and makes him perform his characteristic activity well (Nicomachean Ethics no. 1106a 20).

Virtue is a state "that every virtue causes that of which it is a virtue to be in a good state, and to perform its characteristic activity well." (Nicomachean Ethics no. 11061 15). In other 
words, without virtues, nobody can be a good person and can perform their activity well. Therefore, virtue is a statement of characters which make good condition possible and makes the work of that thing to be done well. This is one of the most important elements on why somebody has to pursue virtues in such a way that it will become a trait or character of that person.

Understanding and exercising well the good characters will make a good habit so that doing good become a habitual daily life and the finally become a virtue. Certainly, understanding the good does not means that a person is a good person. It needs further step, a choice that is wise, and an act to do that wise choice. Pellegrino E, et al. [2] correctly writes, "The acts of the virtuous person proceed from three things: knowledge of the good in any actions, a choice of the good for its own sake, and a source for knowledge and choice in a good character. It is the traits of good character that ensure that the right and good will not only be recognized but also chosen" [2].

Sometimes, the act of choosing is not always to choose between good and bad, but sometime between bad and worse (Minus Malum) or between good and the best (maximum bonum). There are many such choices in medical services: amputations, surgeries, and pain killer are examples of minus malum choice while plastic surgery and human enhancement are examples of maximum bonum choice. Virtues need prerequisite of choosing wisely. For medical students, to be trained to choose wisely according to the sound ethical principles in order to become virtuous physicians is essential.

\section{Virtuous Physicians in Indonesia}

As Socrates said that virtues are product of reason and so they can be taught and trained (Meno 70.a), Indonesian government issued a Law on the Education of Physicians in 2013. It is clearly said in that law that the virtues of physician must be taught in the faculty of medicine so that physicians have virtuous character such as noble, dignified, professional, dedicated, and committed to ethical principles. So, educating medical student to be virtuous physicians is not only an ethical duty but also a legal duty.

Indonesian Medical Council issued National Standard for Medical Professional Education in 2019. In the Introduction of the Standard, it is underlined that physicians must have the ability to perform their duties in a virtuous manner. The first competency to evaluate the alumni of a medical faculty is virtuous professionalism. It is not enough that an alumnus has an average standard of professionalism (having knowledge and skill, service orientation, and obeying medical ethics). Virtuous professionalism is defined as having virtuous character, patient safety orientation, sacrifices his personal interest for the benefit of their patients, and has the social and humanity dedication.

In 2012, The Indonesian Medical Council issued Competency Standard for Indonesian Physicians. The first competency in the area of virtuous professionalism includes believe in one almighty God, high standard of morality, ethics, and self-discipline, comply and obey the laws, cultural and social insight, and professional behavior. The description of virtues is not traditionally but in conformity with the Indonesian way of life: Pancasila, in which the first principle of Pancasila is to believe in one almighty God. Uniting medical profession with Divinity is historically understandable and furthermore it binds the physicians to implement their virtues in medical services.

To underline the necessity of physicians to have lived a virtuous life, The Indonesian Medical Association (IDI) set up Code of Conduct for Indonesian physicians (Kode Etik Kedokteran Indonesia 2012) to achieve that. In the preamble of the Code, virtue and nobility of medical professional are emphasized as the continuation of medical professional since the down of the civilization. The medical professional is a virtuous professional because it deals with the humanity so that human being must be placed in first place in all of their professional activity.

The virtue of a person will be visible in decision making. Making decision is very important in medical service because almost everything in medical service follow after a decision: what will be done, how much the cost, what will be needed in medical service, which will perform the service and so on. We have to discuss about making decision in relation to virtue. The title of the second article of the Code, "Standard of good medical service". One of the elements of good medical service is making professional decision. In making professional decision, physicians should make harmonious combination between medical technics and ethics which has the root at the totality of the service and the virtuous professional behavior (Code no. 2.2). The other things that the code also emphasizes are about making decision in medical dilemma (Code no. 2.5). When physicians face ethical dilemma in their services, it is obligatory for physicians to act according to their virtuous professionalism, at least according to the golden rule of the virtue: "Treat others as you would like others to treat you and do not treat others in ways that you would not like to be treated'.

\section{Concluding Notes}

Medical profession has long been regarded as the oldest of virtuous profession and become the model of other virtuous professions. It is because physicians directly 
deal with suffering and vulnerable person and need high standard of compassion and care. The virtuous physician is inseparable part of it. The need of virtuous physicians is more needed now because the erosion of the virtue becoming more apparent.

In the year 2009, Indonesian government enacted law on hospital, in which private company was given permission to build profit-oriented hospital. Step by step, it changes the orientation of hospital from humanity into profit. The effect of this change to the medical personals is also immense. In some cases, physicians are more profit-oriented rather than humanity oriented. It eroded the virtues of medical ethics.

Although the virtues of physicians have been taught since the first year in faculty of medicine, valued by standard of competency and continued being mandated by Code of Conduct for Indonesian physicians, it cannot stop the erosion its virtues. Here and there we heard the violation of the virtues. It needs bigger efforts to maintain the application of the virtues so that patients are being served with maximum benefit, as the Hippocrates Oath says, "I will apply dietetic measures for the benefit of the sick according to my ability and judgment; I will keep them from harm and injustice."

\section{References}

1. Aristotle, Nicomachean Ethics

2. Edmund P, Thomasma DC (1993) The Virtues in Medical Practice. Oxford University, pp: 5. 